\title{
Developing Engineering Communicative Competency through Effective Assessment Methods
}

\author{
Rohani Othman
}

\begin{abstract}
A great importance of engineering education over the last decade has been on the development of some very specific non-technical attributes which included communication skills, the ability to function in teams, knowledge of societal and contemporary issues, development of global perspective, and ethics awareness. These non-technical skills complement a strong technical foundation to produce well-rounded engineering graduates who are flexible and adaptable to suit the constantly developing and changing requirements of the workplace. The industry as well as the international and local accreditation bodies have repeatedly highlighted the importance of strong communication skills for engineers entering the workplace [1][7]. Industries require a greater number of communication and interpersonal skills for entry-level engineers [8], yet, graduate engineers still lack the required standard of communication skills [9]. Engineering communication competency, especially in the English language is essential for an engineer who aspires to carry out his/her professional practice in the global economy. Similarly, the challenges faced by graduates are to focus on the development of the professional skills in the undergraduate engineering program in order to meet the demands from industries. As such the Malaysian higher education system must produce graduates who can communicate effectively in English. Otherwise, it would lose one of its vital selling points for foreign investors to ensure that the skilled labor forces are sufficient to support internationally competitive commerce and industry and to provide individuals with opportunities to optimize their potentials [10], [11].
\end{abstract}

Index Terms: Assessing communication skills, Engineering accreditation bodies, Engineering communication competency, Engineering education.

\section{INTRODUCTION}

Universities have realized that in major engineering courses, students' communicative inability especially in oral presentation skills were very low [12]. Reference [13] contends that communication skills are a regular feature of an engineer's job. Fresh graduates employed in the industries have identified that communication skills instructions needs to be improved given the industrialdemands. The industries expect engineering graduates to have strong acquisition of the English language besides being able to communicate effectively.In reviewing engineering communication competence, the literature that follows will provide examples of how engineering communication is categorized with great importance alongside the other hard core skills. It cannot be implied that engineering communication is secondary to or more easily developed than the other "hard" technical expertise [14].

\section{COMMUNICATION COMPETENY IN THE ENGINEERING ACCREDITATION CRITERIA}

An engineering education system of a country needs to be regulated and endorsed as a member nation of the Washington Accord (WA). The WA has demonstrated a strong, long-term commitment to quality assurance in producing engineers ready for industry practice in the international scene. Hence, it is essential for engineering degree programs in Malaysia, through its engineering accreditation council (EAC) to receive due recognition as being substantially equivalent for accreditation by WA. Malaysia was admitted to the Washington Accord as a provisional signatory nation in 2003 [15]. This development has been described as "significant in the history of the Washington Accord" since Malaysia provides a special reference to developing countries.Malaysia joined the other 12 full signatory members which implied that these nations have demonstrated that their accreditation systems are conceptually similar to those of other international accredited engineering education programs. The two most important elements in the WA are that it:

i. Recommends that graduates of accredited programs bemutually recognized as having met the academicrequirements for entry to the practice of engineering in anymember country, and;

ii. Establishes that graduates of programs accredited by theaccreditation organizations of each member nation areprepared to practice engineering at the entry level.

Within the Malaysian context, the Engineering Accreditation Council's (EAC) Engineering Program Accreditation Manual[2], outlines ten learning outcomes that encompasses both the technical and non-technical skills which are considered essential for graduating engineers. Similarly, the Accreditation Board of Engineering and Technology (ABET) Criterion 3 [16], outlines eleven criterion which targeted many of these as essential program outcomes in order for engineering programs to be accredited and which are seen as critical for the success in the twenty first century. Engineering communication competence is one of the outcomes required by an undergraduate engineering program in the Engineering Accreditation Council (EAC) for Institutions of Higher Learning (IHL) in Malaysia as well as in the ABET Engineering Criteria 2000 [16]. The next section highlights the significance and implications of local and international engineering accreditation standards which recognize engineering communication competence as one of the outcomes expected by an undergraduate engineering programs. 


\section{A. Local Engineering Accreditation Standards}

In the local context, the implementation of policy and accreditation is ascertained by the Board of Engineers Malaysia (BEM) through the Engineering Accreditation Council (EAC). BEM outlines ten learning outcomes as a measurement of students' achievement.These learning outcomes distinguish the varying competencies as to what a student will be able to do at the end of a period of study. They are based on ten domains:

i. Ability to acquire and apply knowledge of science andengineering fundamentals;

ii. Acquired in depth technical competence in a specificengineering discipline;

iii. Ability to undertake problem identification, formulationand solution;

iv. Ability to utilize systems approach to design andevaluate operational performance;

v. Understanding of the principles of design for sustainabledevelopment;

vi. Understanding of professional and ethical responsibiliesand commitment to them;

vii. Ability to communicate effectively, not only withengineers but also with the community at large;

viii. Ability to function effectively as an individual and in agroup with thecapacity to be a leader or manager;

ix. Understanding of the social, cultural, globalandenvironmentalresponsibilities of a professionalengineer; and

x. Recognizing the need to undertake lifelong learning,andpossessing/acquiring the capacity to do so.

The one essential to communication skill outcome is item (vii) which emphasizes the students "ability to communicate effectively, not only with engineers but also with the community at large" [2, p. 15]. EAC evaluates programs leading to the award of engineering degrees and accredits local engineering degree programs offered in the Malaysian Institutions of Higher Learning (IHL).EAC also ensures that IHL abide to the accreditation standards to adequately prepare graduates for registration and membership into BEM and the Institute of Engineers Malaysia (IEM) [2, p. 1]. These accreditation standards require engineering programs to train students to function collaboratively, to acquire particular sets of competencies and to communicate effectively to fulfilcommon design objectives.For the faculty, the accreditation standards require a thorough understanding of achievement targets and incorporation of sound assessment criteria.

One of the institutions of higher learning (IHL) in Malaysia, the Malaysia University of Technology or better known locally as Universiti Teknologi Malaysia (UTM), has even drawn up its own set of seven graduate attributes in line with it vision and mission statement. The communicative skills development aspiration of a UTM graduate is for the students to be able to incorporate the ability to communicateeffectively in Bahasa Melayu and English across a range of contexts and audiences and have the:

i. Ability to present information and express ideasclearly,effectively and confidently through writtenand oral modes;

ii. Ability to actively listen and respond to the ideas ofother people;

iii. Ability to negotiate and reach agreement;

iv. Ability to make clear and confident presentationappropriate to audience; and the

v. Ability to use technology in presentation.

UTM is committed to graduating competent, creative and versatile professionals, who are guided by high moral and ethical values in the service of God and mankind. This will require graduates with sound disciplinary and professional knowledge, high self-esteem and effective skills in communication; teamwork; critical thinking and problem solving; lifelong learning and information management; ethics and integrity; entrepreneurship skills; and finally leadership skills [17].

\section{B. International Engineering Accreditation Standards}

Three of the accredited engineering degree programs provided by the accrediting bodies of the Washington Accord [4] include Accreditation Board for Engineering and Technology (ABET), the Institution of Engineering Australia (IEA) and Institute for Electrical and Electronics Engineers (IEEE).Effective communicative ability is one of the key attributes in an undergraduate engineering program required by any engineering accreditation standards. For example, the Accreditation Board for Engineering and Technology (ABET) Criterion 3(g) states that, students should have an ability to communicate effectively. The professional attributes emphasized by the Institution of Engineering Australia (IEA) requires engineers to have the ability to communicate effectively with the engineering team and the community at large [1], [3], [18].This is followed by the Institute for Electrical and Electronics Engineering (IEEE) undergraduate engineering degree curriculum which continually stresses the teaching of communications along with the acquisition of technical knowledge.

\section{International Engineering Accreditation Standards}

ABET is one of the most established and recognized signatory accreditation bodies of the Washington Accord and is subsequently responsible for the accreditation of every major engineering program throughout the United States while the Institution of Engineering Australia (IEA) represents a strong representative of all the countries in the Asia Pacific Region including Malaysia. ABET has introduced the Engineering 2000 Criteria (EC2000) which requires engineering programs to entail eleven program outcomes [16]. The ABET Engineering Criteria 3g [16], recognize the communication skills development as one of the outcomes expected by an undergraduate engineering program by the time they graduate as shown in Table 1.ABET has played a significant role in developing major skills among students in engineering programs. In a study conducted by [19], two of ABET's engineering program outcomes including an ability to communicate effectively and an ability to function on multi-disciplinary teams were assessed in the engineering program. It was revealed that fresh engineers to engineering programs are inadequately exposed to oral communication skills, report writing, technical writing, note-taking, and math skills. However, these skills were developed as 
students were exposed to them in courses such Introduction to Engineering, and Engineering Graphics.

Table 1:Key ABET Program Outcomes EC 2000 Criterion 3-

\begin{tabular}{|l|l|}
\hline \hline \multicolumn{2}{|c|}{ EC 2000 Criterion 3- } \\
\hline \hline a. & $\begin{array}{l}\text { An ability to apply knowledge of mathematics, } \\
\text { science and engineering }\end{array}$ \\
\hline b. & $\begin{array}{l}\text { An ability to design and conduct experiments, as } \\
\text { well as to analyze and interpret data }\end{array}$ \\
\hline c. & $\begin{array}{l}\text { An ability to design a system, component, or process } \\
\text { to meet desired needs }\end{array}$ \\
\hline d. & An ability to function on multi-disciplinary teams \\
\hline e. & $\begin{array}{l}\text { An ability to identify, formulate and solve } \\
\text { engineering problems }\end{array}$ \\
\hline \hline f. & $\begin{array}{l}\text { An understanding of professional and ethical } \\
\text { responsibility }\end{array}$ \\
\hline g. & An ability to communicate effectively \\
\hline h. & $\begin{array}{l}\text { The broad education necessary to understand the } \\
\text { impact of engineering solutions in a global and } \\
\text { societal context }\end{array}$ \\
\hline i. & $\begin{array}{l}\text { A recognition for the need for, and an ability to } \\
\text { engage in life-long learning }\end{array}$ \\
\hline j. & A knowledge of contemporary issues \\
\hline k. & $\begin{array}{l}\text { An ability to use the techniques, skills and modern } \\
\text { engineering tools necessary for engineering practice }\end{array}$ \\
\hline \hline Source:
\end{tabular}
Source: $[16$, p.1]

\section{Institution of Engineering Australia (IEA)}

The Institution of Engineering Australia [3] is another accreditation standard that puts emphasis on communication skills. The one related to communication skills is "the ability to communicate effectively, with the engineering team and with the community at large" which is in item PE3.1 and it has four stages of competencies as shown in Table 2 below.

Table 2: IEA's Communication Skills Attributes (PE 3.1)

\begin{tabular}{|l|l|}
\hline \hline PE & \multicolumn{1}{|c|}{$\begin{array}{c}\text { Key points related to Communication Skills } \\
\text { Outcome }\end{array}$} \\
\hline \hline a. & High level of competence in spoken English; \\
\hline b. & $\begin{array}{l}\text { Ability to make effective oral presentations to } \\
\text { technical and non-technical audience }\end{array}$ \\
\hline c. & $\begin{array}{l}\text { Capacity to hear and comprehend others' } \\
\text { viewpoints as well as convey information; }\end{array}$ \\
\hline d. & $\begin{array}{l}\text { Effectiveness in discussion and negotiation and in } \\
\text { presenting arguments clearly and concisely; }\end{array}$ \\
\hline e. & $\begin{array}{l}\text { Ability to represent engineering issues and the } \\
\text { engineering profession to the broader community. }\end{array}$ \\
\hline \hline
\end{tabular}

Source: [3, p. 9]

\section{Institute for Electrical and Electronics Engineers (IEEE)}

Another international engineering body is the Institute for Electrical and Electronics Engineers [18]. Table 3 provides a detailed explanation on the integration of communication skills practiced in the IEEE program offerings.

Table 3: IEEE Communication Skills Attributes

\begin{tabular}{|c|c|}
\hline $\begin{array}{l}\text { Chapter } \\
5(5.7)\end{array}$ & $\begin{array}{c}\text { Key points related to Communication } \\
\text { Skills Outcome }\end{array}$ \\
\hline a. & $\begin{array}{l}\text { Communicate ideas effectively in written } \\
\text { form; this should include technical writing }\end{array}$ \\
\hline
\end{tabular}

\begin{tabular}{|l|l|}
\hline \hline & $\begin{array}{l}\text { experiences (e.g. of specifications, } \\
\text { requirements, safety cases, documentation) as } \\
\text { well as report writing and this should address } \\
\text { the use of figures, diagrams and appropriate } \\
\text { references; }\end{array}$ \\
\hline b. & $\begin{array}{l}\text { Make effective oral presentations, both } \\
\text { formally and informally; }\end{array}$ \\
\hline c. & $\begin{array}{l}\text { Understand and offer constructive critiques of } \\
\text { the presentations of others; }\end{array}$ \\
\hline d. & $\begin{array}{l}\text { Argue (politely yet effectively) in defense of } \\
\text { a position; }\end{array}$ \\
\hline e. & $\begin{array}{l}\text { Extract requirements from a customer by } \\
\text { careful and penetrating questions using a } \\
\text { disciplined and structured approach; }\end{array}$ \\
\hline f. & Demonstrate the capabilities of a product. \\
\hline \hline
\end{tabular}

Source: [18, p. 23-24]

\section{ASSESSING COMMUNICATION IN AN ENGINEERING PROGRAM}

Engineering education has transformed from the traditional course which highly focuses on technical communication towards an integrated communication courses and design projects. This change is supported by the all the engineering standard mentioned earlier especially for programs at the advanced level which states that any engineer should be able to communicate in the realistic context of a design project. Engineering programs must include "... an engineering project or research activity resulting in a report that demonstrates both mastery of the subject matter and a high level of communication skills" [20]. It is important to note that communicative competency among engineers encompasses much more than mechanical and grammatical correctness or clear text organization. ABET obviously favors assessment of communication skills in an integrated, project-based context.

In ensuring that engineering students are able to function collaboratively and acquire particular sets of competencies to communicate effectively and fulfil common program objectives, a variety of innovative and rigorous methods have been developed by engineering programs in the international context to develop and assess communication skills to be in line with the ABET Engineering Criteria 2000 [21] - [28]. Thus, assessing students' performance to demonstrate accountability has become a necessity in academia. This view supports ABET Criterion 3 which states that:

"...each accredited engineering program must have an assessment program with documented results. The assessment process must demonstrate that outcomes are important to the mission of the institution and the objectives of the program are being measured" [16, p. 3].

The communication skills attributes of graduating undergraduate engineers are best assessed using performance assessment where students are judged on their ability to complete a real task compared to the traditional objective tests which focus on non-contextual recall of facts and closed-ended problem-solving [29]. Reference[30], identified seven types of indicators or instruments that could be used in assessing programs outcomes - Alumni survey, Capstone design courses, 
Employer survey, Exit interviews, Fundamentals of Engineering (FE) Examination, Nationally Standardized Tests, and Industrial Advisory Boards. Simultaneously, ABET provides engineering programs the opportunity to define themselves, their students, and their methods of data collection,

"Evidence must be given that the results (of program assessment) are applied to the further development and improvement of the program. The assessment process must demonstrate that the outcomes important to the mission of the institution and the objectives of the program..., are being measured. Evidence that may be used includes, but is not limited to the following: student's design projects; nationally-normed subject content examinations; alumni surveys that document professional accomplishments and career development activities; employer surveys; and placement data of graduates" [16, p. 3].

Reference [26] categorized the professional skill outcome such as communication skills as 'process skills' and it is one skill that can be taught and assessed. Assessing student performance to demonstrate accountability has become a necessity in academia. This view supports ABET Criterion 3 which states that, "...each accredited engineering program must have an assessment program with documented results. The assessment process must demonstrate that outcomes are important to the mission of the institution and the objectives of the program are being measured" [16, p. 3]. In assessing performance skills, [29] proposed the setting of goals and objectives compatible with the departmental program outcomes and defining appropriate student performance criteria as well as testing a scoring rubric.

The move towards more integrated and university-wide processes for evaluation suggests that assessment should take place from a multi-methodological position. In the all too familiar testing culture, outcomes are based on ranking. An assessment culture using an integrative approach can focus on a wider range of student outcomes - both quantitative and qualitative, that include core engineering courses integrated along with demonstrated proficiency in communication skills. References [30], [31] proposed the use of capstone design courses or final year project (FYP) courses as it serves to integrate previous coursework and requires students to perform at a professional level, demonstrating technical expertise and communication skills. The FYP, if implemented accordingly, provides a unique milestone where the combined skills and conceptual attributes of the undergraduate engineering experience can be measured. In addition, an assessment of student confidence in their ability to work individually or in a team; design, build and test mechanical components, devices or systems; work closely with a faculty member and solve design problems with realistic constraints can be made.

Based on this, [32] conducted an extensive research on the assessment of oral communication skills in English by the engineering students, focusing on how much the oral communication skills have been implemented and emphasized in the Final Year Project II (FYP II) design course, in doing activities such as giving oral presentation and product demonstration. Since the FYP II is the cornerstone of an engineering program, communication skills should have been fully developed by the students by the time they implement their FYP II. This is because the focus in FYP II is on consolidating all the experiences catered towards "research" and learning something new. It requires students working individually, designing, building and testing mechanical components, devices or systems and working closely with a faculty member. Incorporating tasks on communications alongside the design project tasks is beneficial in achieving congruency in the expected students' learning outcome. The study also identified specific, detailed, and measurable attributes from two perspectives - the course outcomes and the program outcomes of the communication skills ability. They describes the level of communication skills competency students are expected to acquire or be able to do by the time they graduate. Given this context and the importance in the assessment of Course Outcomes (CO) and Program Outcomes (PO), this research provided a review of the use of a multiple method approach in the direct assessment of the oral communication skills in the FYPII design course of the graduating engineering students.

Accordingly, [33] stressed that Malaysian higher learning institutions offering engineering programs have to adopt the outcome based education (OBE) as part of the requirement for BEM to be a full member of the Washington Accord. This transformation requires the engineering programs to ensure that the program educational objectives (PEO) and program outcomes (PO) are continually reviewed and the achievement measured within a certain time frame as part of quality assurance process. Reference [30] acknowledge that outcome indicators are the measuring instruments used in assessment, and the means by which achievements of outcomes is confirmed. In general, assessment begins when a program faculty establishes intended program outcomes and then identifies the outcome indicators that will be used to measure the outcomes.

The justification in the use of the mixed method approach in this study was a way of collaborating across education, social science and engineering disciplinary boundaries in future educational settings. Reference[34], indicated that the selection of each individual direct assessment method is based on comparing advantages and disadvantages on the kind of information each method provided and the ease in facilitating cross validation with other methods. As such the use of the two assessment tools gave information about the graduating students' performance in the oral communication skills ability. On a similar note, [35] states that there is no single existing instrument that would be valid, appropriate, or relevant for this particular learning experience. However, items from existing instruments that have established utility and credibility for assessing specific aspects of professional learning experience can be adopted. In addition, it is to take the opportunity to develop a comprehensive and robust picture of student learning and competency in communication skills, and to contribute to the development of new educational experiences or policies related to senior research design experiences. It is also to be responsive to the exploratory nature of the research questions and finally, it is to determine if the instruments used in this study would be an effective means for future assessment of student learning within an engineering learning environment. Since no 
particular method is more privileged over the other, the choice must be driven by the research questions.

An effective assessment of the communication skills learning outcomes used in an engineering program is crucial. A study was conducted by [8] on Universiti Kebangsaan Malaysia (UKM) students' generic skills attributes and its proponents as stipulated in the engineering accreditation standards. It only rated the learning outcomes as outlined in the EAC manual from the highest to the lowest. In another UKM study, [36] proposed a capstone design project to develop students ability in many of the EAC criteria to introduce the learning outcomes. Therefore, the present challenge is to utilize assessment instruments that adequately address observable evidence of learning outcomes. Measures are needed for engineering educators to develop effective assessment tools for course and program evaluation [35]. These measures will provide a better understanding of the active learning process, and the means for students to take a proactive role in their learning. Similarly, documenting learning outcomes could provide evidence of continuous improvement for the department.

\section{CONCLUSION}

One of the most important aspects of course assessment processes is "closing the loop" by providing feedback to the department so that improvements could be made where The current educational reform seen worldwide in the move towards a common framework in achieving international accreditation through assessment goals and practices and without large-scale assessments at the program level, deficiencies will not be recognized or addressed; and academic departments may continue with the status quo which may or may not be instructionally effective [37]. Though UTM recognizes the importance of communication skills and effective communication skills is seen as a key attribute of its graduates for success in employment, efforts must be made by UTM and its engineering departments to ensure continuous evaluation of communication skills in the engineering curriculum, and to place a higher priority on the teaching and strong usage of communication skills alongside the technical skills. These issues have to be seriously considered in order to upgrade the ranking of UTM to be equivalent to the curriculum standards of universities that have received international accreditation standards.

\section{REFERENCES}

1. ABET, Accreditation Board for Engineering and Technology, Criteria for Accrediting Engineering Programs. 2007, ABET,, Engineering Accreditation Commission.

2. BEM, Board of Engineers Malaysia, Engineering Programme Accreditation Manual, T.I.o.E. IEM, Malaysia, Editor. 2007, IEM.

3. IEA, The Institution of Engineering Australia, Engineers Australia National Generic Competency Standards - Stage 1 Competency Standards for Professional Engineers. Education Programs at the Level of Professional Engineer, ed. A.M. System. 2005.

4. IEM, The Institution of Engineers Malaysia. Accreditation. 2008 [cited 200818 September, 2008]; Available from: www.iem.org.my.

5. McKenzie, L.J., et al., Capstone Design Courses and Assessment: A Conference \& Exposition, A. American Society for Engineeering Education, Editor. 2004, ASEE: Salt Lake City, UT. warranted and strengths and weaknesses could be identified. National Study, in American Society of Engineering Education Annual

6. Paretti, M.C., Teaching Communication in Capstone Design: The Role of the Instructor in Situated Learning. Journal of Engineering Education, 2008. 97(4): p. 13.

7. Sageev, P. and C.J. Romanowski, A Message from Recent Engineering Graduates in the Workplace: Results of a Survey on Technical Communication Skills. Journal of Engineering Education, 2001: p. 9.

8. Azami, Z. A Gap Study between Employers' Perception and Expectation of Engineering Graduates in Malaysia. in 5th WSEAS / IASME International Conference on ENGINEERING EDUCATION 2008. Heraklion, Greece.

9. Forbes, S., Report on The First University-Industry Dialogue (1stUID) Group work discussion, T.M.I.C.o.C.a. Industry, Editor. 2005: Kuala Lumpur, Malaysia.

10. Muhammad Rashid Rajuddin, Prof., Dr. . Keynote Address on Technical and Vocational Education in Malaysia. in Conference on Technical and Vocational Education in Malaysia. 2006. Hotel Sofitel, Senai, Johor. UTM.

11. Riemer, M.J., English and Communication Skills for the Global Engineer. Global Journal of Engineering Education, 2002. 6(1): p. 91 100.

12. IPPTN, The National Higher Education Research Institute, University Curriculum: An Evaluation on Preparing Graduates for Employment. IPPTN, National Higher Education Research Institute, 2006.

13. Riemer, M.J., Communication Skills for the 21st Century Engineer. Global Journal of Engineering Education, 2007. 11(1): p. 1 - 12.

14. Wilk, R.D. and A.M. Anderson. Development of Communication Skills Across the Engineering Curriculum. in American Society for Engineering Education Annual Conference \& Exposition. 2002.

15. Accord, W., The Washington Accord. 2007.

16. ABET, Accreditation Board for Engineering and Technology, ABET Engineering Criteria. 2000, Accreditation Board for Engineering and Technology, Inc.

17. UTM, Universiti Teknologi Malaysia, Seven Attributes of UTM Graduates. 2008: UTM Skudai, Johor.

18. IEEE, Institute for Electrical and Electronics Engineers Report on Curriculum Guildeline for Undergraduate Engineering Program. 2004, IEEE-CS.

19. Agoki, G.S., B.C. Ng, and R.L. Johnson. Development of Communication Skills and Teamwork amongst Undergraduate Engineering Students. in 37th ASEE/IEEE Frontiers in Education Conference. 2007. Milwaukee: ASEE.

20. ABET, Accreditation Board for Engineering and Technology, Criteria for accrediting engineering programs: Effective for evaluations during the 2002-2003 accreditation cycle 2003.

21. Felder, R.M. and R. Brent, Designing and Teaching Courses to Satisfy the ABET Engineering Criteria. Journal of Engineering Education, 2003.

22. Lang, C.R. and H. Gurocak. Assessment Methods for the Upcoming ABET Accreditation Criteria for Computer Science. in 38th ASEE/IEEE Frontiers in Education Conference. 2008. Saratoga Springs, NY: ASEE/IEEE.

23. McGourty, J., M. Besterfield-Sacre, and L. Shuman. ABET's Eleven Student Learning Outcomes (a-k): Have We Considered The Implications? in ASEE. 1999a. Charlotte, North Carolina ASEE.

24. McGourty, J., et al., Preparing for ABET EC 2000: Research-Based Assessment Methods and Processes. International Journal of Engineering Education, 2002. 18(2): p. 157-167.

25. Mickelson, S.K., et al. Development of Workplace Competencies Sufficient to Measure ABET Outcomes. in ASEE Annual Conference \& Exposition. 2001. ASEE.

26. Shuman, L.J., M. Besterfield-Sacre, and J. McGourty, The ABET "Professional Skills" - Can They Be Taught? Can They Be Assessed? Journal of Engineering Education, 2005. 94(1): p. 41.

27. Tooley, M.S. and K.D. Hall. Using a capstone design to facilitate ABET 2000 Program Outcomes. in ASEE Annual Conference of Engineering Education: Education to Serve the World. 1999. Charlotte, NC: ASEE.

28. Williams, J.M. Transformations in technical communication pedagogy: engineering, writing, and the ABET Engineering Criteria 2000 in Technology \& Teamwork. 2000.

29. Miller, R.L. and B.M. Olds. Performance Assessment of EC-2000 Student Outcomes in the Unit Operations Laboratory in ASEE Annual Conference \& Exposition. 1999. Charlotte, North Carolina: ASEE.

30. Scales, K., et al., Preparing for Program Accreditation Review Under ABET Engineering Criteria 2000: Choosing Outcome Indicators. Journal of Engineering Education, 1998. 87(3). 
31. Duff, J.M. and T.E. Schildgen. Establishing Outcomes for Senior Capstone Projects In Industrial Technology. in 2005 American Society for Engineering Education Annual Conference \& Exposition. 2005. American Society for Engineering Education.

32. Othman, R., ASSESSING ORAL COMMUNICATION SKILLS IN THE FINAL YEARENGINEERING DESIGN PROJECT, in Language Academy. 2016, Universiti Teknologi Malaysia: Johor Baru.

33. Shahrir, A., et al. Implementing Continual Review of Programme Educational Objectives and Outcomes for OBE Curriculum Based on Stakeholders' Input. in 7th WSEAS International Conference on EDUCATION and EDUCATIONAL TECHNOLOGY. 2008.

34. Adams, R.S., et al., Assessment of an International Freshmen Research and Design Experience: A Triangulation Study. International Journal of Engineering Education, 2002. 18(2): p. 180-192.

35. McGourty, J., Four Strategies to Integrate Assessment into the Engineering Educational Environment. Journal of Engineering Education, 1999b: p. 391 - 395.

36. Riza Atiq, O.K.R., et al., Capstone Project to Satisfy EAC Criteria, in Seminar Pengajaran dan Pembelajaran Berkesan 2005, UKM, Editor. 2005.

37. Racicot, K. and C. Pezeshki. Active Assessment in Engineering Design Using a Systems Approach. in ASEE Annual Conference and Exposition 2007. 2007. Honolulu, Hawaii: ASEE.

\section{AUTHORS PROFILE}

Rohani Othmanis a Senior Lecturer at the Language Academy, Universiti Teknologi Malaysia. She has a strong academic base and experience of more than 30 years teaching English at the tertiary level. Realizing the importance for other disciplines such as Engineering, Science, IT and Built Environment to developed Communication-based competencies and to master and apply English in a Multidisciplinary context, Rohani completed her PhD thesis integrating communication into the engineering course and evaluating students' achievement in the communication skills outcomes. Currently, she is the main supervisor to three $\mathrm{PhD}$ and two Masters students. Her research areas included Engineering Education; Engineering Communication, Communication at Workplace, Multidisciplinary Research, Assessment of Communication Skills Learning / Program Outcome and Outcome-Based Education (OBE). 